\title{
Literature Review on Why Q Theory Didn't Work
}

\author{
Qianwen Ding \\ College of Economics, Ji'nan University, Guangzhou, China \\ Email: DQW_JNU2016@163.com
}

How to cite this paper: Ding, Q.W. (2019) Literature Review on Why Q Theory Didn't Work. Modern Economy, 10, 986-993. https://doi.org/10.4236/me.2019.103066

Received: February 27, 2019

Accepted: March 23, 2019

Published: March 26, 2019

Copyright $\odot 2019$ by author(s) and Scientific Research Publishing Inc. This work is licensed under the Creative Commons Attribution International License (CC BY 4.0).

http://creativecommons.org/licenses/by/4.0/

\begin{abstract}
This paper briefly reviewed the investment theory-Q theory and explained why $\mathrm{Q}$ theory cannot indicate the change of investment from the perspective of cash flow and misvaluation. I further demonstrated the foreign research and domestic research on the channel through which misvaluation influent investment.
\end{abstract}

\section{Keywords \\ Q Theory, Investment, Misvaluation, Cash Flow}

\section{Investment Theory}

As one of the most important part of the real economy, investment will not only affect short-term employment and economic growth, but also lead to economic cycle fluctuations [1]. Investment is driven by many factors; one of them is the stock market. The relationship between stock market and investment has been studied for a long time. $q$ Theory is one of the most important theory explaining the investment and stock market which was proposed by Tobin in 1969. The theory concludes that the optimal investment depends on the present value of $q$ by introducing a simple adjustment cost function and thus links $q$ ratio (the ratio of a firm's market value to its replacement cost) to investment. If $q>1$, the market value of the enterprise is greater than the replacement cost, which means the purchase of newly produced capital goods is more favorable than the existing capital goods, the enterprise should increase investment; On the contrary, if $<1$, enterprises should reduce investment [2]. Hayashi (1982) further demonstrated the relationship between average $q$ and marginal $q$ and he proved that when an enterprise is a price-taker and the production function and adjustment cost function are linear, marginal $q$ is equal to average $q$. The above research conclu- 
sions provide convenience for subsequent scholars to test the $q$ theory [3].

\section{Reasons of Q Theory Didn't Work?}

Many empirical studies found that the $q$ theory could not explain why investment changes. This has triggered a wide academic discussion on this issue.

\subsection{The Effect of Cash Flow}

One class of literature is explained from the perspective of cash flow. According to Fazzari et al. (1988), investment demand only depends on investment cost if all enterprises can obtain external financing and internal and external financing can replace freely. But if an enterprise is subject to financing constraints, due to the existence of "financing hierarchy", internal cash flow has cost advantages and investment is limited by internal cash flow [4]. They take the investmentcash flow sensitivity as evidence to support financing constraints. However, Kaplan and Zingales (1997) analyzed the enterprises identified by Fazzari et al. (1988) as having high cash flow sensitivity, and drew a totally different conclusion from them that enterprises with low financing constraints have stronger cash flow sensitivity, while those with high financing constraints have weaker cash flow sensitivity. The debate between these two views has been long and inconclusive [5].

\subsection{The Effect of Rationality and Measurement Error of Proxy Variables}

Scholars continue to explain it from the perspectives of the rationality and accuracy of proxy variables which was used to measure the financing constraints. Abel and Eberly (2011) constructed a model without considering financing constraints and adjustment costs and found that both cash flow and Tobin $q$ were significantly sensitive to investment. They believed that the sensitivity of "investment-cash flow" was due to the fact that cash flow contained long-term information not captured by other variables [6]. Another type of literature is explained in terms of measurement errors. Erickson and Whited (2000) pointed out that the failure of $q$ theory was due to the measurement error of marginal $q$. Through the study of listed companies in the United States, they found that if the error is controlled properly, the cash flow does not have a significant impact on investment, and the source of measurement error is using the average $q$ as the proxy variable of marginal $q[7]$.

\subsection{The Impact of Misvaluation}

There is another type of literature that explains theoretical failure from the perspective of misvaluation. A large number of empirical research results show that stock market has bubbles because the fluctuation of stock price far exceeds the fluctuation of dividend flow which means stock price deviates from the intrinsic value of enterprises [8]. Therefore, if the stock market misestimates the 
intrinsic value of listed companies, will the misvaluation have an impact on investment? Many scholars made theoretical contributions to this issue. One group of scholars focuses on the discussion of whether the intrinsic value of enterprises or the stock price reflecting investor expectation influent investment. Morck et al. (1990) believed that the stock market is a passive predictor of future activities. When stock price is contrary to the judgment of investment decision makers on intrinsic value, he will not let stock price influent investment [9]. Blanchard et al. (1993) hold the same view. He decomposed Tobin q into two parts including intrinsic value and the part of misvaluation and then use investment to regress on the two parts respectively using the annual data from 1900 to 1988. He found that misvaluation has a limit impact on investment by comparing the two residual of the regression under the assumtion of the same regression coefficient [10]. However, Barro (1990) proved that even if cash flow variables exist, the change of stock price plays a decisive role in investment of American company [11]. Chen et al. (2007) tested the relation between stock price information content and investment sensitivity, and found that no matter whether the stock price deviates from intrinsic value, the information or signals reflected by the stock price will be used as the judgment basis for enterprise making investment decisions, and the more information the stock price contains, the stronger the investment sensitivity of the stock price will be [12]. Bond and Cummins (2001) believed that when the stock market's valuation of an enterprise deviates from its intrinsic value, the error caused by using stock price to calculate average $q$ will lead to $q$ theory's failure [13].

Nevertheless, another type of literature does not distinguish whether the intrinsic value or bubbles have an impact on investment. They only build a model comparing the actual price with the real price, and indirectly judges the impact of mispricing on investment by analyzing error terms. Chirinko and Schaller $(1996,2001,2011)$ indirectly tested whether there is misvaluation and whether misvaluation affects investment by constructing $q$ equation and Euler equation deprived from the first order conditions of the optimal decision-making model. If both $q$ equation and Euler equation are correctly specified, it means that there is no misvaluation in stock market. If the $q$ equation is hold, and the Euler equation is correct specified, it indicates that the stock market was misestimated, but misvaluation did not affect investment; if both $q$ equation and Euler equation are not valid, it indicates that misvaluation existed in stock market and affect investment. Chirinko and Schaller (1996) tested the two equations using the overall data of American non-financial enterprises from 1911 to 1987 and found that American stock market was misvalued but this did not influent American investment [14]. However, Chirinko and Schaller (2011) did the same empirical test using the panel data of listed American companies from 1980 to 2004 and found that the misvaluation in the stock market had an impact on investment. They believe that this difference is due to the fact that the panel data of listed companies are more diverse, which contains more information and is more ac- 
curate [15]. On the other hand, the period from 1980 to 2004 includes the 1990 s of the United States. Some scholars have observed that misvaluation impact investment indeed, which was not included during this period and this period was not included in the previous test. Chirinko and Schaller (2001) studied the Japanese stock market which is more volatile and found that the misvaluation led to $6 \%-9 \%$ increase of fixed asset investment from 1987 to 1989, which was equivalent to $1 \%-2 \%$ of GDP in that year [16].

\section{The Channel of Misvaluation Affecting Investment}

\subsection{Foreign Research}

In addition, many scholars further discussed the channels through which misvaluation influent the investment. Stein (1996) discussed under what circumstances the stock price would affect investment from the perspective of discount rate. He believed that the manager of an overvalued company with a short-term vision would use a lower discount rate and increase investment while the manager of an undervalued company facing financing constraints will use a higher discount rate because of the cost of raising capital and thus reduce investment [17]. Baker et al. (2003) found that in equity-dependent enterprises, investment is more sensitive to stock price changes [18]. Gilchrist et al. (2005) analyzed the path of stock price influent investment from equity financing channels, and believed that high stock price would reduce the financing cost of enterprises and alleviate the degree of financing constraint of enterprises, and enterprises tended to issue more shares and improve the actual investment [19]. Campello and Graham (2013) also concluded that high stock prices affect corporate policies because the ease financing constaints [20]. Hau and Lai (2013) proved the firms underestimated have considerably lower investment and employment and this effect is found to be more common on the most financially constrained firms [21]. Warusawitharana and whited (2016) found that misevaluation affects equity values and firms optimally issue and repurchase overvalued and undervalued shares [22]. Polk and Sapienza (2008) introduced the catering mechanism. In their model, it was assumed that investors predicted stock price changes based on the investment expenditure of enterprises, and managers would choose projects with negative cash flow to increase investment in order to cater to investors [23].

\subsection{Domestic Research}

Domestic scholars concentrated on the empirical test of the theory. Ding Shouhai (2006) tested the $q$ hypothesis using the quarterly data of listed companies from 1994 to 2005, based on the statistical characteristics of the data structure of vector autoregressive (SVAR) method, and the results showed that the Tobin $q$ and investment exist strong reverse effect and our country exists obvious "Anti-Tobin $q$ " phenomenon. $Q$ value cannot instruct investment but lead to irrational investment which means investment in our country is irrational [24]. Lian 
Yujun and Cheng Jian (2007) found that investment expenditure is still very sensitive to cash flow under the control of Tobin $q$ error. Both the "anti-Tobin $q$ phenomenon" and the investment-cash flow sensitivity imply the failure of $q$ theory.

Some scholars try to explain the theory's failure by studying the reasons why investment-cash flow sensitivity exist [25]. Qu Wenzhou et al. (2011) introduced information asymmetry into the framework of investment-cash flow sensitivity analysis, and found that the higher the level of information asymmetry, the lower the level of investment, and the higher the level of information asymmetry, the higher the sensitivity of investment-cash flow [26]. Zeng Ai'min et al. (2013) tested the influence of financing constraint and financial flexibility on the sensitivity of investment-cash flow, and found that financing constraint was one of the reasons for the generation of investment-cash flow. Further analysis found that in enterprises with large financing constraint, the sensitivity of investment-cash flow was positively correlated with financial flexibility [27]. Other scholars try to analyze the impact of misvaluation of listed companies on investment to explore the reasons for theoretical failure. Li Jieyu and Wang Meijin (2006) explore whether the bubble influence investment from the perspective of equity division using the unbalanced panel data from 1992 to 2003. They use average daily turnover rate as proxy variable of bubbles using PVAR method, empirical analysis results show that the shareholders holding period the relationship between bubble and investment decision, in float for large enterprises, the bubble has significant effects on investment [28]. Li Junping and Xu Longbing (2015) based on the perspective of financing constraints and regressed investment on corporate fundamentals and misvaluation part using the annual data of listed companies from 2000 to 2012 . The empirical results show that the stock market mispricing has a significant influence on investment, but mainly in enterprise facing strong financing constraints and mispricing has no significantly influence on the company with low financing constraints [29].

Domestic scholars also further test the channel including the equity financing mechanism and catering mechanism through which misvaluation affect investment. Liu duan and Chen Shou (2006) and Hao ying and Liu Xing (2009) all confirmed the existence of equity financing mechanism, and found that the greater the degree of equity-dependent, the more sensitive the investment is to stock price, which is consistent with Baker et al. (2003) [30] [31]. However, Guo jie and Zhang Yingbo (2012) believe that under the specific background of China's equity financing regulation, enterprises cannot independently choose the timing of listing and the number of issuing shares, so equity financing channels may be ineffective [32]. Xiao hong and Qu Xiaohui (2012), based on the perspective of the interaction between investors and listed companies, confirmed the hypothesis of R \& D investment catering behavior. Further research found that catering effect mainly exists in private listed companies [33]. Qu Wenzhou et al. (2016) obtained the proxy variables of intrinsic value and speculative bubbles based on the decomposition of asset pricing model under heterogeneous beliefs, 
and used regression analysis to verify the equity financing channels and the pandering mechanism channels that stock prices affect investment, and found that bubbles would stimulate enterprise investment. In the non-financing constraint group, the bubble affects investment mainly through the channel of catering mechanism. In the financing constraint group, bubbles mainly affect investment through equity financing channels [34].

\section{Conclusion}

Through the review of the literature on why Q theory didn't work, we can find that there is no consistent explanation for the question. But we can be inspired by former research and avoid some mistakes and probably come up with some good ideas. Maybe next we would work out the problem of measurement error of proxy variables and try out some new tests.

\section{Conflicts of Interest}

The author declares no conflicts of interest regarding the publication of this paper.

\section{References}

[1] Chen, L., Da, Z. and Larrain, B. (2016) What Moves Investment Growth? Journal of Money, Credit and Banking, 48, 1613-1653. https://doi.org/10.1111/jmcb.12360

[2] Tobin, J.A. (1969) General Equilibrium Approach to Monetary Theory. Journal of Money, Credit and Banking, 1, 15-29. https://doi.org/10.2307/1991374

[3] Hayashi, F. (1982) Tobin's Marginal q and Average q: A Neoclassical Interpretation. Econometrica, 50, 213-224. https://doi.org/10.2307/1912538

[4] Fazzari, S.M., Hubbard, R.G. and Petersen, B.C. (1988) Financing Constraints and Corporate Investment. Brookings Papers on Economic Activity, 1988, 141-206. https://doi.org/10.2307/2534426

[5] Kaplan, S.N. and Zingales, L. (1997) Do Investment-Cash Flow Sensitivities Provide Useful Measures of Financing Constraints? The Quarterly Journal of Economics, 112, 169-215. https://doi.org/10.1162/003355397555163

[6] Abel, A.B. and Eberly, J.C. (2011) How Q and Cash Flow Affect Investment without Frictions: An Analytic Explanation. The Review of Economic Studies, 78, 1179-1200. https://doi.org/10.1093/restud/rdr006

[7] Erickson, T. and Whited, T.M. (2000) Measurement Error and the Relationship between Investment and q. Journal of Political Economy, 108, 1027. https://doi.org/10.1086/317670

[8] West, K.D. (1987) A Specification Test for Speculative Bubbles. The Quarterly Journal of Economics, 102, 553-580. https://doi.org/10.2307/1884217

[9] Morck, R., Shleifer, A. and Vishny, R.W. (1990) The Stock Market and Investment: Is the Market a Sideshow? Brookings Papers on Economic Activity, 1990, 157-215. https://doi.org/10.2307/2534506

[10] Blanchard, O., Rhee, C. and Summers, L. (1993) The Stock Market, Profit, and Investment. The Quarterly Journal of Economics, 108, 115-136. https://doi.org/10.2307/2118497

[11] Barro, R.J. (1990) The Stock Market and Investment. The Review of Financial Stu- 
dies, 3, 115-131. https://doi.org/10.1093/rfs/3.1.115

[12] Chen, Q., Goldstein, I. and Jiang, W. (2007) Price Informativeness and Investment Sensitivity to Stock Price. Review of Financial Studies, 20, 619-650. https://doi.org/10.1093/rfs/hhl024

[13] Bond, S. and Cummins, J. (2001) Noisy Share Prices and the Q Model of Investment. IFS Working Papers, Institute for Fiscal Studies (IFS).

[14] Chirinko, R.S. and Schaller, H. (1996) Bubbles, Fundamentals, and Investment: A Multiple Equation Testing Strategy. Journal of Monetary Economics, 38, 47-76. https://doi.org/10.1016/0304-3932(96)01267-6

[15] Chirinko, R.S. and Schaller, H. (2011) Fundamentals, Misvaluation, and Business Investment. Journal of Money, Credit and Banking, 43, 1423-1442. https://doi.org/10.1111/j.1538-4616.2011.00430.x

[16] Chirinko, R.S. and Schaller, H. (2001) Business Fixed Investment and "Bubbles": The Japanese Case. The American Economic Review, 91, 663-680. https://doi.org/10.1257/aer.91.3.663

[17] Abel, A.B. and Blanchard, O.J. (1986) The Present Value of Profits and Savings in Investment. Econometrica, 54, 249-273. https://doi.org/10.2307/1913150

[18] Baker, M., Stein, J.C. and Wurgler, J. (2003) When Does the Market Matter? Stock Prices and the Investment of Equity-Dependent Firms. The Quarterly Journal of Economics, 118, 969-1005. https://doi.org/10.1162/00335530360698478

[19] Gilchrist, S., Himmelberg, C.P. and Huberman, G. (2005) Do Stock Price Bubbles Influence Corporate Investment? Journal of Monetary Economics, 52, 805-827. https://doi.org/10.1016/j.jmoneco.2005.03.003

[20] Campello, M. and Graham, J.R. (2013) Do Stock Prices Influence Corporate Decisions? Evidence from the Technology Bubble. Journal of Financial Economics, 107, 89-110. https://doi.org/10.1016/j.jfineco.2012.08.002

[21] Hau, H. and Lai, S. (2013) Real Effects of Stock Underpricing. Journal of Financial Economics, 108, 392-408. https://doi.org/10.1016/j.jfineco.2012.11.001

[22] Warusawitharana, M. and Whited, T.M. (2016) Equity Market Misvaluation, Financing, and Investment. The Review of Financial Studies, 29, 603-654.

[23] Polk, C. and Sapienza, P. (2008) The Stock Market and Corporate Investment: A Test of Catering Theory. Review of Financial Studies, 22, 187-217. https://doi.org/10.1093/rfs/hhn030

[24] Ding, S. (2006) Does the q Value of Ding Shouhai and Tobin Affect Investment? Another Test of the Rationality of Investment in China. Research on Quantitative Economy and Technical Economy, 12, 146-155.

[25] Lian, Y. and Cheng, J. (2007) Investment-Cash Flow Sensitivity: Financing Constraints or Agency Costs? Financial Research, 2, 37-46.

[26] Qu, W., Xie, Y. and Ye, Y. (2011) Information Asymmetry, Financing Constraint and Investment-Cash Flow Sensitivity: An Empirical Study Based on Market Microstructure Theory. Economic Research, 6, 105-117.

[27] Zeng, A. and Wei, Z. (2013) Financing Constraints, Financial Flexibility and Corporate Investment-Cash Flow Sensitivity-Theoretical Analysis and Empirical Evidence from Chinese Listed Companies. Financial Research, 11, 48-58.

[28] Li, J. and Wang, M. (2006) Real Investment of Listed Companies and Speculative Bubbles in Stock Market. World Economy, 1, 87-95.

[29] Li, J. and Xu, L. (2015) Capital Market Mispricing, Financing Constraints and Corporate Investment. Finance and Trade Economics, 3, 88-102. 
[30] Liu, D. and Chen, S. (2006) The Influence of Stock Price on the Investment Behavior of Chinese Listed Companies-Based on the Empirical Study of Different Equity-Dependent Companies. Management Review, 1, 31-36.

[31] Hao, Y. and Liu, X. (2009) Equity Financing Dependence and Corporate Investment Behavior-From the Perspective of Behavioral Corporate Finance. Journal of Economics and Management, 5, 32-40.

[32] Guo, J. and Zhang, Y. (2012) Does the Enterprise or the Government Choose the Time? The Impact of IPO Market Timing on Capital Structure under Specific Institutional Background in China. Financial Research, 7, 137-153.

[33] Xiao, H. and Qu, X. (2012) R \& D Investment Catering Behavior: Rational Catering Channel and Equity Financing Channel? Based on the Empirical Evidence of Chinese Listed Companies. Accounting Research, 2, 42-49.

[34] Qu, W., Ye, Z. and Yan, L. (2016) Stock Price Bubble Will Affect the Company's Capital Investment? Empirical Test Based on Equity Financing Mechanism and Catering Mechanism. Securities Market Guide, 6, 33-41. 